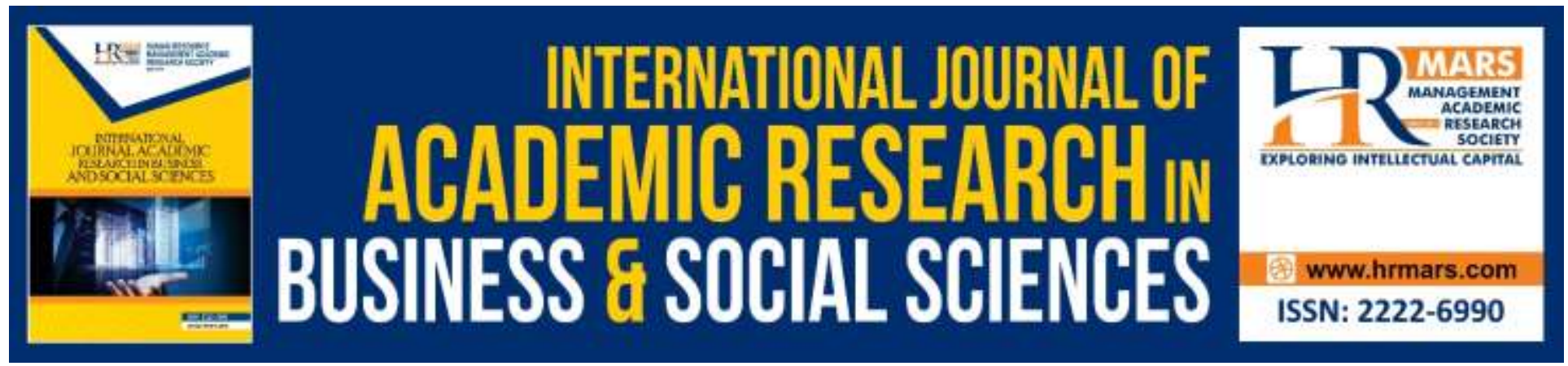

\title{
Risk Reporting Environment in Malaysia and The Influence of Corporate Governance Mechanisms
}

Ag Kaifah Riyard bin Kiflee, Mohd Noor Azli bin Ali Khan, Mathew Kevin Bosi

To Link this Article: http://dx.doi.org/10.6007/IJARBSS/v10-i4/7155

DOI:10.6007/IJARBSS/v10-i4/7155

Received: 02 February 2020, Revised: 07 March 2020, Accepted: 25 March 2020

Published Online: 18 April 2020

In-Text Citation: (Kiflee et al., 2020)

To Cite this Article: Kiflee, A. K. R. bin, Khan, M. N. A. bin A., \& Bosi, M. K. (2020). Risk Reporting Environment in Malaysia and The Influence of Corporate Governance Mechanisms. International Journal of Academic Research in Business and Social Sciences, 10(4), 552-573.

Copyright: (c) 2020 The Author(s)

Published by Human Resource Management Academic Research Society (www.hrmars.com)

This article is published under the Creative Commons Attribution (CC BY 4.0) license. Anyone may reproduce, distribute, translate and create derivative works of this article (for both commercial and non-commercial purposes), subject to full attribution to the original publication and authors. The full terms of this license may be seen at: http://creativecommons.org/licences/by/4.0/legalcode

Vol. 10, No. 4, 2020, Pg. 552 - 573

Full Terms \& Conditions of access and use can be found at http://hrmars.com/index.php/pages/detail/publication-ethics 


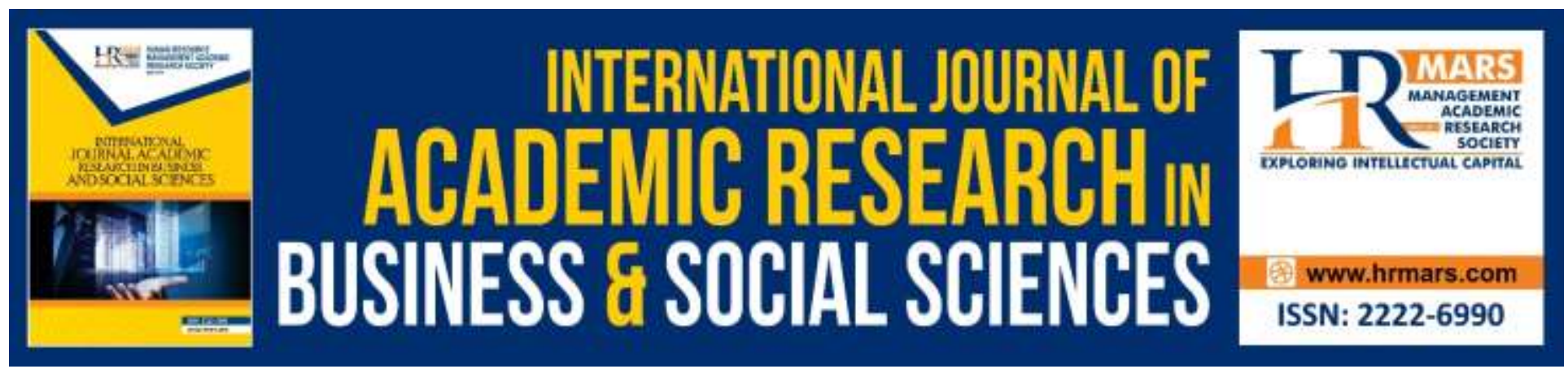

\title{
Risk Reporting Environment in Malaysia and The Influence of Corporate Governance Mechanisms
}

\author{
${ }^{1}$ Ag Kaifah Riyard bin Kiflee, ${ }^{2}$ Mohd Noor Azli bin Ali Khan, \\ ${ }^{3}$ Mathew Kevin Bosi \\ ${ }^{1,3}$ Faculty of Business, Economics and Accountancy, Universiti Malaysia Sabah, ${ }^{2}$ Azman Hashim \\ International Business School, Universiti Teknologi Malaysia,
}

\begin{abstract}
The aim of this study is to investigate the nature of risk information within Malaysia annual report and also to investigate potential determinants who influence the risk disclosure practice. Past accounting scandals and also the failure of financial system in 2007/2008 has triggered the need for sound corporate governance and also comprehensive risk management plan. A total of 167 companies based on a random sample were chosen from Bursa Malaysia from 2008 till 2017. This study also employed content analysis to measure the level of risk information. Based on the result, it is found that for the last 10 years, companies in Malaysia has increase their disclosure practice which this can be refer from the positive upward trend graph. This study found that all the selected corporate governance is positively and significantly influenced the risk disclosure practice among listed companies in Malaysia.
\end{abstract}

Keyword: Risk Disclosure, Corporate Governance, Content Analysis, Malaysia

\section{Introduction}

In general, annual report is an important tool to convey useful information to stakeholder and potential investor as it comprises comprehensive information such as financial and non-financial information (Azlan, Rosli \& Hassan, 2009). However, due to unforeseen internal and external factors, company is exposed to a volatile business environment. Study reported by Ernst \& Young (2014) and Gjerald \& Lyngstad (2015) stated that, one of the factors who contributed to the volatile business environment faced by the company today is non-financial risk such as technical risk, operational risk and strategic risk. This is supported by Abdullah et al. (2015) who agreed that much of business downfall was caused by the inability of the management to properly manage their non-financial risk. Political unrest, a conflict among countries, uncertain government policy also viruses attack is some of the unforeseen risk that totally affects the company growth (Abdullah et al., 2015).

Despite the potential effect that was caused by undisclosed non-financial risk information, the management however still opposed the idea of disclosing the information to the market and rather focus on disclosing more prominent risk information of financial risk information (Lajili \& 
Zéghal, 2005). Similar study also argued that by disclosing such vague non-financial risk information to the market, an inform decision may not be concluded by the investors. It was stated, before investor decided on the investment decision, usually they will observe company performance and their risk management plan (Cabedo \& Tirado, 2004). It also stated that, in a situation whereby the investors make a poor investment decision (cannot assess the company risk information), they may decide to uphold their investment as the probability for severe loss is higher.

After a series of discussions, it was agreed by researchers and standard setters that, high quality corporate reporting should contain significant amount of non-financial risk information together with financial risk information (ICAEW, 1999; CICA, 2009). Study by Solomon et al. $(2000,2011)$ confirmed that, with the disclosure of non-financial risk information from the company, this practice may assist investors to improve their decision making and reduce their concern (Orens \& Lybaert, 2007). Therefore, to enhance their investment capability, investors especially has demanded richer information from the company as the disclosure practice in some countries are considered as optional (Financial Reporting Council (FRC), 2011). Past result study has showed that company may reluctant to disclose risk information as it may impair their competitive advantages upon the competitor (Ali, 2013; FRC, 2011). Arguably, the debate has continued whether it is necessary for the company to disclose information despite the probability of losing their competitive advantage in the market.

In light of the increasing demand for high quality information, past studies has further investigated the potential factors that affect company disclosure level (Saggar \& Singh, 2017). However, it is to note that there are some limitations that associated with previous studies which open for further investigation. It was found that most of the previous studies focus on the effect of company characteristics with risk disclosure (Azlan et al., 2009; Baroma, 2014; Oliveira et al., 2011; Madrigal et al., 2015) and less focus on the effect of corporate governance. By referring to this loophole, this study therefore interested to establish relationship between corporate governance and disclosure practice especially in developing context (Ntim, Lindop \& Thomas, 2013; Said Mokhtar \& Mellett, 2013; Saggar \& Singh, 2017). This study is in general will enrich the current understanding on the risk disclosure and the factors who might affect it.

Result on previous study also suggested that some of the corporate governance attributes were found to have positive and significant relationship with total disclosure level, however, interestingly in different studies, the same corporate governance is showing contradict result. In Malaysia, study on corporate governance and risk disclosure is still limited that tend to generate a mixed result (Zadeh, 2015). This fact alone has motivated the researchers to further examine the effect of corporate governance determinants to total disclosure level among companies in Malaysia.The purpose of this study is to measure the level of risk information being disclosed in the annual report of Malaysian companies and at the same time, identified potential factors who could influence higher disclosure of risk information in the annual report. To realise the research objective, this study indicatively performed content analysis into both sections of the annual report (financial section and non-financial section) to determine the level and type of risk information which listed companies in Malaysia disclose.

This study was organise as follows. In the first section of this study, researcher will focus on discussing the introduction and background of corporate governance in Malaysia. In the next section, this study will explain the theoretical framework employed together with the formation 
of hypotheses. Next, methodology apply will be discussed in the third section of this study followed by the analysis and result. Last section of this study will focus on analysis discussion and conclusion of the study.

\section{Research Objectives}

The following research objectives was formulated in order achieved the aim of this study:

1. To determine the trend of risk disclosure and characteristics of risk information disclosed among listed companies in Malaysia from 2008-2017.

2. To established the relationship between corporate governance determinants with total risk disclosure level in Malaysian companies.

\section{Corporate Governance and Risk Reporting Environment in Malaysia}

Enron, Parmalat and WorldCom are some of the perfect example of corporate governance failure in the past and these scandals have raised concern on the reliability of companies annual report as the primary source of information (Linsley \& Shrives, 2000). On the bright side of these scandals, it allows the company to realise the importance to have sound governance and at the same encourage the company for higher disclosure to the market. In Malaysia, Transmile case back in 2006 is the perfect example of corporate governance failure where it was reported that, the total revenue of the company in the last three years was purposely fabricated (Abdullah Zaimee, 2007; Norwani, Mohamad \& Chek, 2011). Transmile scandal arguably was due to poor monitoring from the board and the failure of governance to ensure the reliability of information discloses (Norwani et al., 2011).

Ghazali (2004) and Zadeh (2015) argued that achieving sound governance is crucially important in order to retain the shareholder and ensuring the management is working at the best interest of shareholders where this could be realised through regulation implementation. Akhtaruddin et al. (2009) convinced that corporate governance could become an essential tool to improve internal control and reduce agency cost. Ho \& Wong (2001) stated that, manager opportunistic behaviour could be reduced under comprehensive monitoring which as a result enhance corporate disclosure due to lower information asymmetry.

In Malaysia, the risk disclosure standard was governed Malaysian Accounting Standard Board (MASB) where one of their objectives is to establish disclosure standard and ensure the standard govern is fulfilling international criteria. Before the establishment of MASB, Malaysian Institute of Accountant (MIA) and Malaysian Institute of Certified Public Accountants (MICPA) is the responsible bodies to set the accounting standard for Malaysian companies. All matters related to the accounting profession were governed under MIA while MICPA is responsible to professionally recognise the accounting profession in Malaysia (Susela, 1999).

To ensure the governance system in Malaysia at the top notch, Malaysian Code of Corporate Governance (MCCG) is the responsible body to establish and approved regulation related to corporate governance in Malaysia. MCCG has been through a series of amendment since 2002 until 2017 to ensure the corporate governance standard in Malaysia is update and align with international need (Akhtaruddin et al., 2009; MCCG, 2017). In addition, Bursa Malaysia also adapted their own listing requirement which compulsory to be abided by listed companies in Malaysia. These codes promote on the need of better transparency, accountability, internal control and board function among listed companies in Malaysia. Corporate governance was 
claimed as an important tool employed by the management to achieve their objectives while disclosure was considered as a communication tool to deliver beneficial information to the public (Akhtaruddin et al., 2009).

Previous researcher argued that information disclosure from a company is considered as their assurance to the market to reduce investor concern. It is to note that most of the previous literature focus on determining the effect of company characteristic to risk disclosure (Chen \& Jaggi, 2000) which left the effect of corporate governance to be further study. Therefore, this study will focus on discussing the effect of corporate governance to company risk disclosure.

\section{Theoretical Development}

\section{Agency Theory}

Following series of major corporate scandals, researcher has worked continuously to investigate the factors and attempt to explain the phenomena behind it by using a series of theories. Among the theories is agency theory studied by Fama \& Jensen (1983) and Jensen \& Meckling (1976). This theory probably is the best theory to explain the incurred agency cost and the disclosure phenomena. Agency theory, based on study conducted by Mallin (2007) is relationship whereby principals (market) entrust the management to the agent (management) with expectations that the agent may maximise the principals' interest. Agency cost present when the probability of separation between ownership and management is higher (Jensen \& Meckling, 1976).

Latham \& Jacobs (2000) explained that, in a situation whereby the shareholder and creditor monitoring mechanism are failure, the manager has the tendency to fully maximise their own interest by manipulating the information. In addition, agency cost also happened when the manager is having extra information than the shareholders, placing the shareholders in an unfavourable situation (Jensen \& Meckling, 1976). Therefore, as a way of reducing the agency cost, the objective between the principals and agent should be aligned through the best possible contract (Healy \& Palepu, 2001). Voluntary disclosure also is one of the possible initiatives that should be employed by the management to reduce agency cost (Barako, Hancock, \& Izan, 2006) as it acting as a signal to the market (Watson, Shrives, \& Marston, 2002). Therefore, in order to improve information asymmetry, corporate governance function may act as the tool to encourage risk disclosure information.

\section{Signalling Theory}

To explain the market phenomena, Robert Jarvis in 1970 introduced the word 'signal' and the definition was keep updating from time to time to suit with the market condition. Throughout the study, it was recorded that, company who having excellent performance have the tendency to signal their prospective strategy in the annual report (Eccles et al. 2001). While, Spence (2002) described signal as a voluntary information disclosure by the agent to the market who usually contains company competitive advantages. In higher information asymmetry situation, it is normal to observe signalling activities from the managers to the markets (Morris, 1987). Signalling theory argued that, due to responsibility of the manager to disclose beneficial information in the market, they may include extra information in the presented annual report (Haniffa \& Cooke, 2002).

Zadeh (2015) stated that, in order for the company to signal their good performance, they might consider to disclose the information the annual report. The study also argued that, signalling 
information through an annual report is the best option considering the function of the annual report as the primary source of information for the market. It also found that, the company may use the signal as a way of obtaining market share (Wallace et al. 1994; Wallace \& Naser, 1995). However, it is to note that in actual business situation, the managers have the privilege either to disclose or withhold information (Ali, 2013). The manager also, in some situation, may purposely withhold information or send misleading signal in the market to secure their company value (Aryani, 2016). It also explained through past studies that, the true intention of the manager in disclosing the information is hardily assessed as the disclosure of information is subjective. Therefore, this study employs signalling theory in order to explain the risk phenomena in Malaysia.

\section{Hypothesis Development}

This study intends to examine the influence of corporate governance attributes (board independence, board size, board gender, auditor independence and audit tenure) to risk disclosure practice in Malaysia. Hypotheses developments are stated as following:

\section{Board Independence}

One of the functions of independent directors on the board is to encourage the disclosure of information among the company by becoming the independent party between the manager and shareholder. Weisbach \& Hermalin (2000) agreed that the role of independent directors is crucial in improving the owner-manager disagreement. However, this only can be achieved if the independent director could properly play their role (Fama \& Jensen, 1983). Akhtaruddin et al. (2009) in their study suggested the proportional of directors in the board arguably play a crucial role in influencing the effectiveness of corporate governance in reducing the information asymmetry. Elshandidy et al. (2013) is other studies also agreed that the degree of disclosure either voluntary or mandatory is heavily influenced by the number of external directors on the board. A study in the UK found that, the existence of an independent party on the board has influence the manager disclosure preference which this at the same time reduces the agency cost (Abraham \& Cox, 2007). However, despite the positive upbringing cause by an independent director, it also argued the existence of an independent director on the board may contribute to poor disclosure decision due to complex board hierarchy (Gul \& Leung, 2004). This may be due to unaligned objective sharing between the manager and independent director who leads to poor decision making (Demb \& Neubauer, 1992).

It also stated, board with a higher proportion of independent director may fail to effectively monitor the manager which leads to higher information asymmetry (Lin, Pope, \& Young, 2003). To enhance shareholder confident, the presence of higher independent director on the board may necessary as independent directors is synonym with the disclosure of higher information quality (Leftwich, Watts \& Zimmerman, 1981; Chen \& Jaggi, 2000; Akhtaruddin et al., 2009). A company was argued to experience a higher level of information disclosure in the presence of external directors. Therefore, the following hypothesis is stated:

$\mathrm{H} 1$ : There is a positive relationship between higher proportion of independent director on board and risk disclosure practice in Malaysian listed companies. 


\section{Board Size}

The level of risk disclosure made by the company was identified as strategic decision by the management of the company. As the company getting bigger with a variety of business, the board of directors now is not only responsible to monitor the management of the company, but also at the same time established a functional policies for directors references (Akhtaruddin et al., 2009). Chen \& Jaggi (2000) agreed that, with the presence of extra members on the board will improve the information asymmetry. Companies with extra board members are found to improve their internal control and also promote higher disclosure among their management (Sheila, Hafiz Majdi, Akhyar, \& Kameel, 2011). However, having large board may also bring negative impact to the company. Companies in UK for example, preferred to have 'manageable' board as it is found to be efficient (Guest, 2008). Zaluki \& Hussin (2009) in the other way around also found no association between size of board and financial disclosure among companies in Malaysia.

Corporate governance function through board size was claimed as the best tool to reduce agency cost due to extra monitoring from directors on the board (Ntim et al., 2013). For the board of director work properly, the member should stand about 7-8 people (Florackis \& Ozkan, 2008; Jensen, 1993). Therefore, based on the argument stated, following hypothesis is posit:

$\mathrm{H} 2$ : There is a negative relationship between larger board size and risk disclosure practice in Malaysian listed companies.

\section{Board Gender}

Al-Shaer \& Zaman (2016) in their sustainability study found that, company with mix gender board are excellent in promoting the quality of sustainability report. Higher quality of sustainability report may be due to personality and communications skills of the female directors who argued for higher disclosure report (Al-Shaer \& Zaman, 2016; Liao, Luo, \& Tang, 2015). It also stated, implementation of risk mitigation among mix gender board is rather efficient due to a variety of directors' experience. However, it is to aware that, despite the existence of female director on the board, size of the board itself was found playing an important role in determining the disclosure level of the company (Michelon \& Parbonetti, 2012).

The presence of female directors on the board also said enhancing the quality of board meeting which in result affect the disclosure practice of the company (Al-Shaer \& Zaman, 2016). In addition, an issue who usually not significant in all gender board, was taken seriously in the mix gender board (Clarke, 2005; Huse \& Solberg, 2006). Joy (2008) also agreed that communication among mix gender board is more effective which allowed large information exchange between the board and the management. Nonetheless, high conflict among director is also recorded in a company with mix gender board (Boone \& Hendriks, 2009; Mannix \& Neale, 2005). This was happening when the directors are standing from different personality and background which lead to conflict among themselves. Based on the argument, this study posit that the existence of mix gender board would be likely to influence higher disclosure.

H3: There is a positive relationship between multi gender board and risk disclosure practice in Malaysian listed companies.

\section{Auditor Independence}

In ensuring only credible report is issued, the external auditor of the company is obligated to preserve their independence, free from internal and external intimidation. This is to ensure the 
annual report presented is free from manipulation, and expressing the real situation of the company (Bakar, Rahman \& Rashid, 2005). It also stated that, most of the auditor independence variable were studied in other fields than disclosure and it was found that, auditor independence plays an exclusively role in improving the financial restatement. It also found that Big 4 auditors due to their status and professional training are literally more independence than non-big 4 (Carcello \& Nagy, 2004).

Stanley \& DeZoort (2007) highlighted that audit fee charged by the firm may determine the degree of auditor independence. In an effort to attract and retained new client, the audit firm may engage in low balling tactics, tactics whereby the audit firm charging lower audit fee in comparison to the other competitors (Sankaraguruswamy \& Whisenant, 2003). It was argued that by participating in such tactics, the auditor independence will be impaired and affect the quality of the report. It also to note that, Big 4 firms usually charged slightly higher audit fee than non-big 4 firms due to their excellent audit output (Tang, Chen, \& Lin, 2016). Thus, the presence of higher independent auditor will affect the company risk disclosure.

H4: There is a positive relationship between auditor independence the level of risk disclosure practice in Malaysian listed companies.

\section{Auditor Tenure}

In relation to a case study in tea factories in Kenya, it was highlighted that the duration of auditor stay is definitely affecting the company disclosure level (Chepkorir, 2013). The study also found that, long association auditor is associated with higher independent auditor. This happened when the auditor is capable to prepare a comprehensive report due to their familiarity over the risk associated by the company (Bakar et al., 2005). In contrast, short auditor tenure was argued to have a higher probability in impairing their independence, affecting the audit and information quality (Chepkorir, 2013). However, at the same time, it also found that long tenure auditor was associated with flexible audit task and unsystematic audit procedure (Mautz \& Sharaf, 1961). SEC in their AAERS (Accounting and Auditing Enforcement Release) report stated, the probability for fraud is higher in the first three years after the auditor appointment (Carcello \& Nagy, 2004). Similar report also found that, longer tenure auditor contributed to company misleading action. However, in different study by Stanley \& DeZoort (2007), it was highlighted as the period of auditor stay getting longer, the quality of financial report and audit task is increasing. Therefore, this study posits that longer tenure auditor contributed to high quality report which enhances the company disclosure.

$\mathrm{H} 5$ : There is a positive relationship between longer auditor tenure and risk disclosure practice in Malaysian listed companies.

\section{Methodology}

\section{Content Analysis}

In particular, this study will be employed content analysis as a way of analysing the level of risk disclosure practice among listed companies in Malaysia. Krippendorff (2004) stated that content analysis is a method of answering the research question and objectives formulated by the study through replicable and acceptable deduction from the information extract. Mohammadi (2017) and Smith \& Taffler (2000) highlighted that content analysis can be divided into two, 'form oriented' and 'meaning oriented'. However, this study employed 'meaning oriented' whereby 
potential themes are identified through the set of keyword in sentences (Bamber \& McMeeking, 2010). In addition, this approach also includes the analysis of negative and positive phrases identifies from the sentences. This method of sentence analysis is arguably align with study conducted by (Azlan et al., 2009; Linsley, Shrives, \& Crumpton, 2006; Zadeh, Zaleha, Rasid, \& Basiruddin, 2016) as it was agreed that the extract data is rather precise, reliable and competence (Milne \& Adler, 1999).

\section{Automated Content Analysis Procedure}

This study employed automated content analysis in order to analyse the risk information as practiced by (Elshandidy, Fraser \& Hussainey, 2013; Elshandidy \& Neri, 2015). In addition, this study also employed sentences as unit of analysis, aligned with previous study of (Azlan et al., 2009; Milne \& Adler, 1999; Mohobbot, 2005). Contently, there are three steps involved in capturing risk information in the company. First, researchers compile a comprehensive list of keywords which they adopted from study (Oliveira, Rodrigues, \& Craig, 2011). The set bag of keywords that were adopted earlier was later divided into three categories, which are financial risk, non-financial risk and risk management framework, which are consistent with study the of (Oliveira et al., 2011).

Next, researcher examines and records the relevant synonym for all the keywords that were identified earlier. Lastly, researcher may identify another relevant keyword out of the set bag of keyword when going through the respective annual reports. To let the researcher understand and familiar with risk sentences, few annual reports were taken and analysed manually where the researcher read the annual report line by line in order to understand the nature of the business and the risk that associated with the company. It also stated that, during the analysis, keywords that was appeared less than five times is eliminated for the final list of the set bag of keywords.

Once the researcher is familiar with the risk sentences, this study adopted AntWordProfiler which is an automated software similar with Nvivo, to assist researcher in determining the keywords in the annual report, aligned with previous study of (Elshandidy \& Neri, 2015).

As the analysis of the annual report is finished, all the scores were checked thoroughly to ensure the reliability: such as a cross checked between total score attained by the researcher in the score sheet and the total score given by the AntWordProfiler.

\section{Sample Size}

This study intends to investigate all non-financial companies listed in Bursa Malaysia for 10 years (2008-2017). However, this study purposely excludes companies who listed in financial, open and close fund and insurance industries. Financial industries were excluded from the sample as they employed special rule and regulation related to disclosure who governs by the Central Bank of Malaysia (Rahmat \& Iskandar, 2004; Abd Aziz, Iskandar \& Saleh, 2006). While, for open and close fund company, it was highlighted that these industries to have their own format set of annual report, incompatible with listed companies in Malaysia (Isa, 2006). A total of 940 companies are listed in Bursa Malaysia as in 2017. However, the researcher only examines the sample which fulfill the criteria as per study by Zadeh et al. (2016). After thorough filtration process, the final sample of 167 companies was analysed by using simple random sampling (Al-Arussi et al., 2009) in order to measure the level of risk information and established the relationship between 
INTERNATIONAL JOURNAL OF ACADEMIC RESEARCH IN BUSINESS AND SOCIAL SCIENCES

Vol. 10, No. 4, April, 2020, E-ISSN: 2222-6990 @ 2020 HRMARS

corporate governance attributes and risk disclosure practiced among listed companies in Malaysia.

\section{Dependent Variable Measurement}

To study the risk information discloses by the companies in Malaysia, this study adopted a content analysis method to capture risk information in the annual report (Abraham \& Cox, 2007; Beretta \& Bozzolan, 2004). Arguably, there are two main methods in content analysis, namely as manual method which is a known method adopted by previous study (Beretta \& Bozzolan, 2004; Lajili \& Zéghal, 2005; Linsley \& Shrives, 2006; Mokhtar \& Mellett, 2013) and recent automated method (Elshandidy, Fraser \& Hussainey, 2013; Elshandidy \& Neri, 2015). Many of the past studies agreed that automated method is a better method of capturing risk information as the probability for lower error is higher.

Both of the methods, can adopt the word, sentence or line as a unit of measurement. Mohobbot (2005), Linsley \& Shrives (2006) and Azlan et al. (2009) have adopted sentences analysis as a unit of measurement. This is in conjunction with Milne \& Adler (1999) who agreed that sentence analysis is rather produced robust analysis than sentences and word counting.

It was stated that, degree relevance of information discloses was determined by examining how much other information being disclosed together (diluted) (Beretta \& Bozzolan, 2004). From a user perspective, company with a lower degree of information disclosure is considered to be risky as the information was vague, making it difficult to assess the whole company system. While from the company perspective, communicating large mass of information in the annual report is considered as a strategy to hide their unfavourable information. This strategy allowed the company to abide with disclosure standards but at the same time makes the readers confuse with massive information disclosure, limiting the reader ability to understand the information discloses (Saggar \& Singh, 2017). This study arguably employed automated content analysis method aligned with study of Elshandidy, Fraser \& Hussainey (2013) and Elshandidy \& Neri (2015) and also sentence analysis as practiced by Linsley \& Shrives (2006), Azlan et al. (2009) and Oliveira et al. (2011) as unit of measurement to measure risk disclosure practice in Malaysia.

Measuring the Independent Variables

In order to determine the effect of corporate governance on risk disclosure practice in Malaysia, this study employed five attributes, namely as board independence, board size, board gender, auditor independence, and auditor tenure. The measurement for all attributed is discussed as following:

Board independence (BID): Board independence is the degree of the independent directors on the board (Yunos, 2011). For the purpose of this study, the proportion of independent directors was manually calculated and collected from the respective annual reports. This method is aligned with a study conducted by Macchioni, Allini \& Rossi (2014) and Allini, Manes Rossi \& Hussainey (2016).

Board size (BSze): Board size can be defined as the total number of directors who sits on the board (Ronnie Lo, 2010). Previous studies by Ahmed \& Duellman (2007), Krishnan \& Visvanathan 
(2008) and Lam \& Lee (2008) was also employed a similar method in determining the board size as the researchers manually collected from the annual reports.

Board Gender (BGdr): Board gender diversity is arguably capable to improve the company disclosure quality and enhance the company performance by enclosing rich information to users (Boone \& Hendriks, 2009; Ray, 2005). Therefore, to measure board gender diversity, this study measure the total number of female director who present on the board, following previous study of Al-Shaer \& Zaman (2016).

Auditor Independence (AUIND): To measure auditors' independence, this study employed the audit fee as studied by Stanley \& Todd DeZoort (2007) and Tang, Chen \& Lin (2016), whereby the total audit fee received is divided with company total assets.

Audit tenure (AUTNR): Audit firm-client relationship is measured through the number of years the audit firms have been working with clients in performing the audit task, consistent with study of Ball et al. (2015).

\section{Empirical Model}

The study is then progress to test the posited hypotheses. In respect to the hypotheses test step, it analyses the effect of corporate governance with the risk disclosure. Model 1 of this study is represented the potential effect of corporate governance attributes to risk disclosure practice in Malaysia.

\section{Model 1}

$$
\text { ToRDL }=\bar{\alpha}_{1}+B_{0}+B_{1} B I D_{i, t}+B_{2} B S Z e_{i, t}+B_{3} B G d r_{i, t}+b_{4} A U I N D i, t+b_{5} A U T N R_{i, t}+\mu_{i}+\mu_{t}+\varepsilon_{i, t}
$$

The $\overline{\boldsymbol{\alpha}}_{1}$ in this model is referring to intercept, while BID is board independence, BSZe, board size, BGdr, board gender diversity, AUIND, auditor independence, AUTNR, auditor tenure, and error term was represented by $\boldsymbol{\varepsilon}$. To achieve a definite result, apart from OLS (ordinary least square), this study also employed fixed effect and random effect test. The fixed effect and random effect analysis was affirmed to be robust than OLS and was used in different studies such as (Milda, 2012; Saleem, 2018) to prove the relationship of the dependent variable.

\section{Result and Analysis \\ Descriptive Statistic for level of Disclosure}

By referring to the result in the Table 1, it can be concluded that all of the risk categories either financial risk, non-financial risk and risk management framework is experiencing increasing trend in term of information disclosure. The result for financial risk indicated that, in average, disclosure for financial risk information is increasing every year for the last 10 years. It is suggested that, based on the result of non-financial risk and risk management framework, it is showed that most of the listed companies in Malaysia prefer to disclose these two types of information, despite stationary trend between 2014 and 2015. By looking at the tabulate result, majority of the sample is preferred to disclose non-financial risk and risk management risk as compared to financial risk. This can be observed from Figure 1 who stated that the disclosure of non-financial risk 
information is leading the other two risk information. Despite the lower disclosure of financial risk and risk management information, in general, this lower disclosure did not significantly affect total disclosure information of the company as the overall trend indicate positive upward progress.

Table 1 Total mean for each risk categories

\begin{tabular}{|l|c|c|c|c|}
\hline & \multicolumn{4}{|c|}{$\sum$ FR + NFR+ KMFW } \\
\hline Year & $N$ & $\begin{array}{c}\text { Financial } \\
\text { Risk }\end{array}$ & $\begin{array}{c}\text { Non- } \\
\text { Financial } \\
\text { Risk }\end{array}$ & $\begin{array}{c}\text { Risk } \\
\text { Management } \\
\text { Framework }\end{array}$ \\
\hline $\mathbf{2 0 0 8}$ & 167 & 11.693 & 12.998 & Mean \\
\hline $\mathbf{2 0 0 9}$ & 167 & 12.014 & 13.367 & 6.435 \\
\hline $\mathbf{2 0 1 0}$ & 167 & 13.952 & 14.364 & 8.114 \\
\hline $\mathbf{2 0 1 1}$ & 167 & 15.683 & 15.317 & 10.667 \\
\hline $\mathbf{2 0 1 2}$ & 167 & 16.183 & 16.626 & 12.442 \\
\hline $\mathbf{2 0 1 3}$ & 167 & 17.023 & 18.973 & 14.235 \\
\hline $\mathbf{2 0 1 4}$ & 167 & 16.969 & 18.920 & 14.175 \\
\hline $\mathbf{2 0 1 5}$ & 167 & 17.526 & 20.180 & 15.252 \\
\hline $\mathbf{2 0 1 6}$ & 167 & 18.023 & 21.590 & 16.101 \\
\hline $\mathbf{2 0 1 7}$ & 167 & 19.187 & 24.141 & 19.136 \\
\hline
\end{tabular}

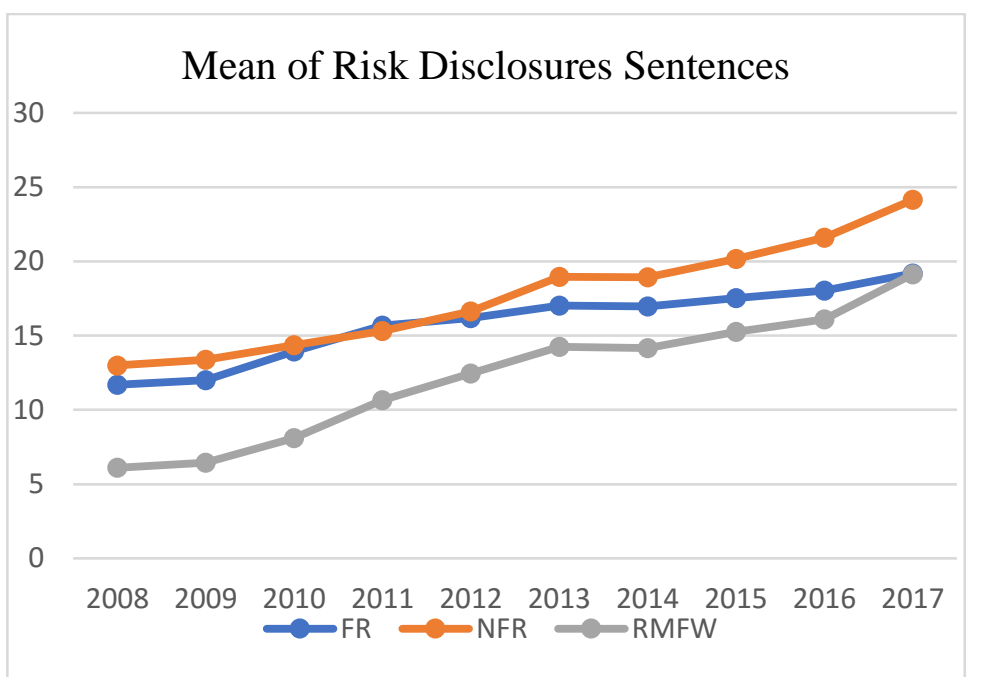

Figure 1 Graph for each risk categories

\section{Fixed Effect Analysis for Model 1}

This study arguably employed fixed effect and random effect analysis to the study model in order to generate robust analysis. Before selecting either to run fixed effect or random effect analysis for the model, it is necessary for the researcher to run Breusch-Pagan Lagrangian Multiplier (BP- 
LM) test to ensure either random effect analysis or OLS test should be employed for the study model. In addition, researcher also should run Hausman test post to BP-LM test, to ensure the model was analysis properly and produce a robust result.

The analysis result of model 1 in Table 1 suggested that the selected corporate governance has a higher probability to influence risk disclosure practice. This can be confirmed from the $F$ statistics and $p$-value result of $(F=69.26)$ and $(<0.000)$ which suggested the probability for company disclosure to be affected by corporate governance is higher. In other ways around, the R-square model suggested that, only $20 \%$ of the study model were explained by total risk disclosure.

While, the result of coefficient and $p$-value of the model 1 showed that, it was argued that all the attributes choose is influencing the company disclosure practice. This can be affirmed by referring to the result of coefficient and $p$-value of board independence (coefficient $=10.0485, p$ value $=0.001$ ), board size (coefficient $=-3.9447, p$-value $=0.043)$, board gender diversity (coefficient $=9.5648, p$-value $=0.038)$, auditor independence $($ coefficient $=162.151, p$-value $=$ 0.046 ) and auditor tenure (coefficient $=8.2883$, $p$-value $=0.000$ ).

Based on the analysis result, corporate governance attributes such as board independence, board gender diversity, auditor independence and auditor tenure are positively influence the disclosure practice of the company while board size in different state, may reduce the total disclosure from the company based on the negative coefficient result.

\begin{tabular}{|c|c|c|}
\hline \multicolumn{3}{|l|}{ Model 1} \\
\hline \multicolumn{3}{|c|}{$\begin{aligned} T R D L= & \bar{\alpha}_{1}+B_{1} B I D_{i, t}+B_{2} B S Z e_{i, t}+b_{3} B G d r_{i, t}+b_{4} A U I N D i_{i, t}+b_{5} A U T N R_{i, t}+b_{6} A C I N D_{i, t}+ \\
& { }_{7} A C E X P_{i, t}+ \\
& { }_{a} O W C O N_{i, t}+b_{b} A T T D I S_{i, t}+\delta_{1} S_{I Z E_{i, t}}+\delta_{2} L E V_{i, t}+\mu_{i}+\mu_{t}+\varepsilon_{i, t}\end{aligned}$} \\
\hline R-Square & 0.1999 & \\
\hline F-Statistics & 69.26 & \\
\hline Prob (F- Statistics) & 0.000 & \\
\hline Independent Variables & Coefficients & $\mathrm{P}$-value \\
\hline BID & 10.0485 & 0.001 \\
\hline Bsze & -3.9447 & 0.043 \\
\hline ToFemDirec & 9.5648 & 0.038 \\
\hline AUDIND & 162.151 & 0.046 \\
\hline AUTRN1 & 8.2883 & 0.000 \\
\hline
\end{tabular}

\section{Analysis Discussion}

\section{Board Independence}

The result suggested that board independence is positively influencing the disclosure practice among listed companies in Malaysia. The outcome is attuned with the posit hypothesis who expected positive relationship between the degree of board independence and total disclosure. The result also revealed that company with higher independent director tends to urge the management to disclose higher information disclosure. This could happen when the independent 
director actively performs their role, stressing the need for higher quality among the management (Zadeh, 2015) which later enhance the quality of financial report (Fama \& Jensen, 1983). In addition, the result also confirming the proposed theory, who argued that, the presence of higher independent director will enhance management performance, especially in relation to disclosure practice (Donnelly \& Mulcahy, 2008). Guay, Samuels \& Taylor (2016) also agreed that, manager may enhance their transparency when being monitored by external directors. Zadeh (2015) at the same tune also confirmed that the management tends to stress the importance of information disclosure in the presence of an independent director. This may happen as the manager intended to show to the board of directors that they are working at the best interest of shareholder, by abiding with disclosure standards.

\section{Board Size}

Previous studies by Ntim et al., (2013) and Xie et al., (2003) agreed that the total number of directors sits on the board is playing a significant role in influencing listed companies disclosure practice (Elzahar \& Hussainey, 2012). However, the result of this study is contradicted with the attained result of previous studies where the result suggested that an increase in total number directors on the board will lower the company transparency. The result however, is harmonised with previous studies of Guest (2008) and Jensen (1993) who documented that board size may not influence the disclosure practice among UK listed companies. They recorded that listed companies in the UK preferred small size board as it is rather more functional due its ability to fully maximise the role of directors (Guest, 2008).

It is argued that board size is often associated with the ability of the company to monitor the manager behaviour (Karamanou \& Vafeas, 2005). Their study recorded that the value of company risk management plan is increasing in the presence of greater board size. Despite that, it also contends that lower board flexibility and efficiency are often associated with large board size. Karamanou \& Vafeas (2005) in the same study also found that the disclosure of management earning information is not affecting by the number of directors sits on the board. Besides, it also stated that large board often being related with poor disclosure decision making, thereby affecting the shareholder investment to the company. Therefore, it can be concluded that the presence of large board lowers the degree of transparency of the company.

\section{Board Gender}

Based on the significant value for the analysis of board gender, it can be confirmed that the existence of female directors on the board is influencing the total disclosure of the company. Therefore, $\mathrm{H} 4$ who stated that there is a positive and significant relationship between board gender and total disclosure is supported.

This study finding arguably attuned with previous study of Al-Shaer \& Zaman (2016) who found an association between female directors and level of disclosure of company. It was stated the variety of multi-gender director background is one of the crucial factors who influence the company disclosure practice. Their personality, expertise and education level may influence their decision against the company transparency (Al-Shaer \& Zaman, 2016; Liao et al., 2015). In addition, Manetti \& Toccafondi (2012) also confirmed that the presence of female director on the board improves the communication between stakeholder which at the same time strengthen 
the director role. It also stated that, higher disclosure by the company may be due to the personality of a female director who quite sensitive over social and ethical issues (Hafsi \& Turgut, 2013). 1MDB (1 Malaysian Development Berhad) and MISC (Malaysian International Shipping Comission) scandals may probably trigger the female director to enhance company disclosure practice.

\section{Auditor Independence}

From the analysis result, it can be observed that degree of auditor independence does affect the company disclosure level. Arguably, it was important for the auditor to secure their independence to allow them to issue high quality of the annual report, free from bias and manipulation. The analysis result is also aligned with proposing agency theory who stated that a higher degree of auditor independence will enhance the company financial reporting quality (Wahab, Gist, \& Majid, 2014).

Previous study suggested that auditor independence was measured through the audit fee charged (Stanley \& Todd DeZoort, 2007) and it was found that, the audit firm may purposely charge below market price in order to attract and retain their client. This action afraid may impair auditor independence and affect the quality of the annual report. However, the result attained was contradicted with previous study result which suggested that, the audit fee charged by the audit firm is equivalent with their assigned task.

\section{Auditor Tenure}

Based on the analysis, it was recommended that the period of auditor stay is positively and significantly affect the company disclosure level. This can be observed from the significant $p$ value which confirmed the $\mathrm{H} 5$ of this study is not rejected. It was argued that the relationship term between the auditor and the company is affecting the company disclosure practice. This is consistent with the result documented by Chepkorir (2013) who found that there is an association between long association auditor and degree of transparency practice in the company. Additionally, it also stated, long term auditor has a higher probability to produce a high-quality report.

Similar study also found that, company with short tenure auditor, tend to have lower audit quality service and poor annual report (Chepkorir, 2013). This is however aligned with the study conducted by Mansi, Maxwell \& Miller (2004) and Ghosh \& Moon (2005) who found a linear relationship between long association auditor and financial report quality. Therefore, based on the notion of argument, it can be stated that the presence of long-term auditor enhances the quality and disclosure practice of the company.

\section{Conclusions}

The objective of this study is to examine the level and the factors who might influences disclosure practices among listed companies in Malaysia. To capture risk information, this study focuses to analyse the non-financial part of the annual report as it was argued that most of the risk information is embedded in the narrative section of the annual report. As confirmed by descriptive statistics, it was found that disclosure practice among listed companies in Malaysia is experiencing positive upward trend with non-financial risk information is the leading risk 
information disclose followed by financial risk and risk management. This is however, in accordance with the requirement of Bursa Malaysia that was stated earlier. The outcome of this study confirmed that board independence, board size, presence of female director, auditor independence and association of auditor are affecting disclosure practice of the company. As the company getting larger, the number of shareholders is getting higher, and this pool of shareholder more than interested to keep updating with company performance.

This study arguably has established relationship factors with total risk disclosure level among listed companies in Malaysia and it was expected that the outcome of this study will further extend the disclosure literature as the researchers arguably has tested determinants that found to be significant in developed countries may also significant in developing countries. Through the outcome of this study as well, the regulatory bodies able to focus on which corporate governance attributes that able to enhance total disclosure level of companies in Malaysia. Past Asian financial crisis 1997 and global economic crisis 2008 have inspired the company to strengthen their corporate governance and enhance their transparency.

It also mentioned that regulator and other professional bodies are responsible to establish a comprehensive risk framework which allows the companies to further understand their own associated risk and at the same time, enhancing the investor's decision value. In Malaysia, it was debated that sufficient information disclosure will speed the investment decision by the current and prospective investors. It was stated, the employed risk framework will allow the manager to evaluate their company risk appetite and determine the characteristics of the risk information. study outcome arguably beneficial especially to corporate disclosure researchers, standard setters and professional organisations as they able to identify type of information being disclosed and the factors (corporate governance) who influence the risk disclosure practice. Risk in the company ultimately will exist and effective mitigation tool is needed in order to improve the information asymmetry. This study it not frees from limitations. One of the constraints that were identified is this study ignoring the financial companies which this may affect the generalization result. Future researcher may interest to investigate different effect of factors that might affect the disclosure practice in the company.

\section{Acknowledgement}

This paper is the revise version of paper presented at the FGIC $2^{\text {nd }}$ Conference on Governance and Integrity from 19 $19^{\text {th }}-20^{\text {th }}$ August 2019 at Universiti Malaysia Pahang, Pahang, Malaysia.

\section{References}

Abd Aziz, N.H., Iskandar, M. T., \& Saleh, M. N. (2006). Pengurusan Perolehan: Peranan Kualiti Audit Dan Urus Tadbir Korporat. International Journal of Management Studies, 13(Special Issue), 163-188.

Abdullah, M., Abdul Shukor, Z., Mohamed, Z. M., \& Ahmad, A. (2015). Risk management disclosure: A study on the effect of voluntary risk management disclosure towards firms value. Journal of Applied Accounting Research, 16(3), 400-432.

Abraham, S., \& Cox, P. (2007). Analysing the determinants of narrative risk information in UK FTSE 100 annual reports. British Accounting Review, 39(3), 227-248. 
Abu Bakar, B. N., Abdul Rahman, R. A., \& Abdul Rashid, M. H. (2005). Factors influencing auditor independence: Malaysian loan officers' perceptions. Managerial Auditing Journal, 20(8), 804-822.

Ahmed, A. S. \& Duellman, S. (2007). Accounting conservatism and board of director characteristics: An empirical analysis. Journal of Accounting and Economics, 43(2-3), 411437.

Akhtaruddin, M., Hossain, M. A., Hossain, M., \& Yao, L. (2009). Corporate Governance and Voluntary Disclosure in Corporate Annual Reports of Malaysian Listed Firms. Journal of Applied Management Accounting Research, 7(1), 1-20.

Al-Arussi, A. S., Selamat, M. H., \& Hanefah, X. M. (2009). Determinants of financial and environmental disclosures through the internet by Malaysian companies. Asian Review of Accounting, 17(1), 59-76.

Ali, M. M. (2013). Corporate Risk Disclosure, Upper Management Characteristics, Ownership Structure And Firm Value : Malaysian Evidence. Phd Thesis, RMIT Univerisity

Allini, A., Rossi, M. F., \& Hussainey, K. (2016). The board's role in risk disclosure: an exploratory study of Italian listed state-owned enterprises. Public Money \& Management, 36(2), 113120.

Al-Shaer, H., \& Zaman, M. (2016). Board gender diversity and sustainability reporting quality. Journal of Contemporary Accounting \& Economics, 12(3), 210-222.

Aryani, D. W. I. N. (2016). The Determinants and Value Relevance of Risk Disclosure in the Indonesian Banking Sector. Phd Thesis, Gloucestershire University.

Azlan, A., Rosli, A. M., \& Hassan, C. H. M. (2009). Risk reporting : An exploratory study on risk management disclosure in Malaysian annual reports. Managerial Auditing Journal, 24(1), 39-57.

Ball, F., Tyler, J., \& Wells, P. (2015). Is audit quality impacted by auditor relationships? Journal of Contemporary Accounting and Economics, 11(2), 166-181.

Bamber, M., \& McMeeking, K. (2010). An examination of voluntary financial instruments disclosures in excess of mandatory requirements by UK FTSE 100 non-financial firms. Journal of Applied Accounting Research, 11(2), 133-153.

Barako, D. G., Hancock, P., \& Izan, H. Y. (2006). Factors influencing voluntary corporate disclosure by Kenyan companies. Corporate Governance: An International Review, 14(2), 107-125.

Baroma, B. (2014). The association between the level of risk disclosure and corporation characteristics in the annual reports of Egyptian companies. American Journal of Business, Economics and Management, 2(1), 9-20.

Beretta, S., \& Bozzolan, S. (2004). A framework for the analysis of firm risk communication. International Journal of Accounting, 39(3), 265-288.

Boone, C., \& Hendriks, W. (2009). Top Management Team Diversity and Firm Performance: Moderators of Functional-Background and Locus-of-Control Diversity. Management Science, 55(2), 165-180.

Cabedo, J. D., \& Tirado, J. M. (2004). The disclosure of risk in financial statements. Accounting Forum, 28(2), 181-200.

Canadian Institute of Chartered Accountants (CICA) (2009), MD\&A: Guidance on Preparation.

Carcello, J. V., \& Nagy, A. L. (2004). Client size, auditor specialization and fraudulent financial reporting. Managerial Auditing Journal, 19(5), 651-668. 
Chen, C. J. P., \& Jaggi, B. (2000). Association between independent non-executive directors, family control and financial disclosures in Hong Kong. Journal of Accounting and Public Policy, 19(4-5), 285-310.

Chepkorir, C. (2013). Factors Influencing Auditor's Independence and Accountability: A Case Study of KTDA Affiliated Tea Factories in Bomet and Kericho County, Kenya. Master Thesis, Maasai University.

Clarke, C. J. (2005). The XX factor in the boardroom: why women make better directors. Directors Monthly, (August), 24, 12-14.

Demb, A., \& Neubauer, F. F. (1992). The corporate board: Confronting the paradoxes. Long range planning, 25(3), 9-20.

Donnelly, R., \& Mulcahy, M. (2008). Board structure, ownership, and voluntary disclosure in Ireland. Corporate Governance: An International Review, 16(5), 416-429.

Eccles, R. G., Herz, R. H., \& Keegan, E. (2001). The value reporting revolution: moving beyond the earnings game. New York.

Elshandidy, T., Fraser, I., \& Hussainey, K. (2013). Aggregated, voluntary, and mandatory risk disclosure incentives: Evidence from UK FTSE all-share companies. International Review of Financial Analysis, 30, 320-333.

Elshandidy, T., Fraser, I., \& Hussainey, K. (2015). What drives mandatory and voluntary risk reporting variations across Germany, UK and US? British Accounting Review, 47(4), 376394.

Elzahar, H., \& Hussainey, K. (2012). Determinants of narrative risk disclosures in UK interim reports. The Journal of Risk Finance, 13(2), pp. 133-147.

Ernst and Young (EY) (2014)/ Top 10 risks in telecommunications 2014, available at: www.ey.com/ (accessed January 2019).

Fama, E. F., \& Jensen, M. C. (1983). Separation of Ownership and Control Separation of Ownership and Control. Journal of Law and Economics, 26(2), 301-325.

Financial Reporting Council (FRC) (2011), Boards and risk: a summary of discussions with firms,

Florackis, C., \& Ozkan, A. (2008). Agency costs and corporate governance mechanisms : Evidence for UK firms. International Journal of Managerial Finance, 44(1904), 37-59.

Ghazali, Nazli, A. M. (2004). Exploring Theoretical Explanations of Voluntary Disclosure By Quantitative and Qualitative Investigation: Evidence From Malaysia. Phd Thesis, Strathclyde University.

Ghosh, A., \& Moon, D. (2005). Auditor tenure and perceptions of audit quality. Accounting Review, 80(2), 585-612.

Gjerald, O., \& Lyngstad, H. (2015). Service risk perceptions and risk management strategies in business-to-business tourism partnerships. Tourism Management Perspectives, 13, 7-17.

Guay, W., Samuels, D., \& Taylor, D. (2016) Guiding through the Fog: Financial statement complexity and voluntary disclosure. Journal of Accounting and Economics. Elsevier, 62(2-3), 234-269.

Guest, P. M. (2008). The determinants of board size and composition: Evidence from the UK. Journal of Corporate Finance, 14(1), 51-72.

Gul, F. A., \& Leung, S. (2004). Board leadership, outside directors' expertise and voluntary corporate disclosures. Journal of Accounting and Public Policy, 23(5), 351-379. 
Hafsi, T., \& Turgut, G. (2013). Boardroom diversity and its effect on social performance: Conceptualization and empirical evidence. Journal of business ethics, 112(3), 463-479.

Haniffa, R. M., \& Cooke, T. E. (2002). Culture, corporate governance and disclosure in Malaysian corporations. Abacus, 38(3), 317-349.

Healy, P., \& Palepu, K. (2001). Information asymmetry, corporate disclosure, and the capital markets: A review of the empirical disclostire literature. Journal of Accounting and Economics, 31, 405-440.

Ho, S. S. M., \& Wong, S. K. (2001). A study of the relationship between corporate governance structures and the extent of voluntary disclosure. Journal of International Accounting, Auditing and Taxation, 10(2), 139-156.

http://books.google.com/books?hl=en\&lr=\&id=q657o3M3C8cC\&oi=fnd\&pg=PA3\&dq=content+ analysis+and+introduction+to+its\&ots=bK8kw1JfBZ\&sig=oZChLqLZbPpLe_MUNDIdOt4A vS8\%5Cnpapers2://publication/uuid/91E0B6B2-5CD7-491A-AF76-FADCBF51BA9B

Huse, M., \& Solberg, A. (2006). How Scandinavian women make and can make contributions on corporate boards. Women in Management Review, 21, 113-130.

Institute of Chartered Accountants in England and Wales (ICAEW) (1999a), No Surprises: The investors and advisors, FRC, London, September.

investors and advisors, FRC, London.

Jensen, M. C. (1993). the Modern Industrial Revolution, Exit , and the Failure of Internal Control Systems the Failure of Internal Control Systems. Journal of Finance, 48(3), 831-880.

Jensen, M., \& Meckling, W. (1976). Theory of the firm: Managerial behavior, agency costs and ownership structure. Journal of Financial Economics, 3, 305-360.

Joy, L. (2008). Women board directors in the United States: An eleven-year retrospective. Women on corporate boards of directors. International research and practice, $15-23$.

Karamanou, I., \& Vafeas, N. (2005). The association between corporate boards, audit committees, and management earnings forecasts: An empirical analysis. Journal of Accounting research, 43(3), 453-486.

Kiel, G. C., \& Nicholson, G. J. (2003). Board Composition and Corporate Performance: how the Australian experience informs contrasting theories of corporate governance. Corporate Governance, 11(3), 189-205.

Krippendorff, K. (2004). Content Analysis An Introduction to Its Methodology. an introduction to its methodology. Retrieved from

Krishnan, G. V., \& Visvanathan, G. (2008). Does the SOX definition of an accounting expert matter? The association between Audit committee directors' accounting expertise and accounting conservatism. Contemporary Accounting Research, 25(3).

Lajili, K., \& Zéghal, D. (2005). aAcontent analysis of risk management disclosures in canadian annual reports. Canadian Journal of Administrative Sciences / Revue Canadienne Des Sciences de L\&apos;Administration, 22, 125-142.

Lam, T. Y., \& Lee, S. K. (2008). CEO duality and firm performance: Evidence from Hong Kong, Corporate Governance, 8(3), 299-316.

Latham, C. K., \& Jacobs, F. A. (2000). Monitoring and incentive factors influencing misleading disclosures. Journal of Managerial Issues, 12(2), 169-187. 
Leftwich, R., Watts, R., \& Zimmerman, J. (1981). Voluntary corporate disclosure: the case of interim reporting. Journal of Accounting Research, 19 (Special),50-77.

Liao, L., Luo, L., \& Tang, Q. (2015). Gender diversity, board independence, environmental committee and greenhouse gas disclosure. British Accounting Review, 47(4), 409-424.

Lin, S., Pope, P., \& Young, S. (2003) Stock market reaction to the appointment of outside directors. Journal of Business, Finance and Accounting, 30, 351-82

Linsley, P. M., Shrives, P. J., \& Crumpton, M. (2006). Risk disclosure: An exploratory study of UK and Canadian banks. Journal of Banking Regulation, 7(3-4), 268-282.

Linsley, P., \& Shrives, P. (2000). Risk management and reporting risk in the UK. The Journal of Risk, 3(1), 115-129.

Macchioni, R., Allini, A., \& Rossi, F. M. (2014). Does Corporate Governance Characteristics Affect Non- Financial Risk Disclosure in Government-Owned Companies ? The Italian Experience, Financial reporting, 1, 5-31.

Madrigal, M. H., Guzmán, B. A., \& Guzmán, C. A. (2015). Determinants of corporate risk disclosure in large Spanish companies: a snapshot. Contaduría y Administración, 60, 757-775.

Mallin, C. (2007). Corporate Governance (2nd Ed.): Oxford. New York: University Press Oxford University Press Incorporation.

Manetti, G., \& Toccafondi, S. (2012). The role of stakeholders in sustainability reporting assurance. Journal of Business Ethics, 107(3), 363-377.

Mannix, E., \& Neale, M. A. (2005). What differences make a difference? The promise and reality of diverse teams in organizations. Psychological Science in the Public Interest, Supplement, 6(2), 31-55.

Mansi, S. A., Maxwell, W. F., \& Miller, D. P. (2004). Does auditor quality and tenure matter to investors? Evidence from the bond market, Journal of Accounting Research, 42(4), 755793.

Mautz, R. K., \& Sharaf, H. A. (1961). The philosophy of auditing. USA: American Accounting Association, New York

MCCG. (2017). Malaysian Code on Corporate Governance. Retrieved from https://www.sc.com.my/wp-content/uploads/eng/html/cg/mccg2017.pdf

Michelon, G., \& Parbonetti, A. (2012). The effect of corporate governance on sustainability disclosure. Journal of Management and Governance, 16(3), 477-509.

Milda, S. (2012). Effect of IFRS Adoption and Audit Firm's Governance on Audit Report Lag. Master Thesis, Universiti Teknologi Mara.

Milne, M. J., \& Adler, R. W. (1999). Exploring the reliability of social and environmental disclosures content analysis. Accounting, Auditing \& Accountability Journal, 12(2), 237256.

Mohammadi, M. A. D. (2017). Corporate Governance and Financial Information Disclosure in a Developing Country. Phd Thesis, Universiti Teknologi Malaysia.

Mohd Isa, R. (2006). Graphical Information in Corporate Annual Report: A Survey of Users and Prepares Perceptions. Journal of Financial Reporting \& Accounting, 4(1), 39-60.

Mohobbot, A. M. (2005). Corporate risk reporting practices in annuals reports of japanese companies. International Journal of Accounting Auditing and Performance Evaluation, $4(3), 263-285$. 
Mokhtar, S. E., \& Mellett, H. (2013). Competition, corporate governance, ownership structure and risk reporting. Managerial Auditing Journal, 28(9), 838-865.

Morris, R. D. (1987). Signalling, Agency Theory and Accounting Policy Choice. Accounting and Business Research, 18(69), 47-56.

Norwani, N. M., Mohamad, Z. Z., \& Chek, I. T. (2011). Corporate governance failure and its impact on financial reporting within selected companies. International Journal of Business and Social Science, 2(21), 205-213.

Ntim, C. G., Lindop, S., \& Thomas, D. A. (2013). Corporate governance and risk reporting in South Africa: A study of corporate risk disclosures in the pre- and post-2007/2008 global financial crisis periods. International Review of Financial Analysis, 30, 363-383.

Nuhu, M., \& Hussani, S. M. (2017). Empirical Study of the Relationship between Board of Director Mechanisms and Perceived Performance of Listed Firms in Nigeria. Journal of Accounting and Finance in Emerging Economies, 3(2), 159-178.

Oliveira, J., Rodrigues, L. L., \& Craig, R. (2011). Risk-related Disclosures by Non-finance Companies : Portuguese Practices and Discloser. Managerial Auditing Journal, 26(9), 817839.

Orens, R., \& Lybaert, N. (2007). Does the financial analysts' usage of non-financial information influence the analysts' forecast accuracy? Some evidence from the Belgian sell-side financial analyst. International Journal of Accounting, 3, 237-271.

Rahmat, M. M., \& Iskandar, M. T. (2004). Audit fee premiums from brand name, industry specialization and industry leadership: A study of the post Big 6 merger in Malaysia. Asian Review of Accounting, 12(2), 1-24.

Ray, D. M. (2005). Corporate boards and corporate democracy. Journal of Corporate Citizenship, 20, 93-105.

Saggar, R., \& Singh, B. (2017). Corporate governance and risk reporting: Indian evidence. Managerial Auditing Journal, 32(4-5), 378-405.

Saleem, F. (2018). Earning Management and Corporate Governance Attributes among NonFinancial Listed Firms in Pakistan. Phd Thesis, Universiti Teknologi Malaysia.

Sankaraguruswamy, S., \& Whisenant, S. (2003). Pricing Initial Audit Engagements: Empirical Evidence Following Public Disclosure of Audit Fees. SSRN Electronic Journal.

Sheila, N. H., Majdi, H. A. R., Akhyar, M. A., \& Kameel, A. M. M. (2011). Corporate Governance and Risk Management Information Disclosure in Malaysian Listed Banks: Panel Data Analysis. International Review of Business Research Papers, 7(4), 159-176.

Smith, M., \& Taffler, R. J. (2000). The chairman's statement - A content analysis of discretionary narrative disclosures. Accounting, Auditing \& Accountability Journal, 13(5), 624-647.

Solomon, J. F., Solomon, A., Norton, S. D., Joseph, N. L., Boden, R., Hemmings, D., \& Whittington, G. (2000). a Conceptual Framework for Corporate Risk Disclosure Emerging From the Agenda for Corporate Governance Reform. British Accounting Review, 32(4), 447-478.

Solomon, J.F., Solomon, A., Norton, S.D. \& Joseph, N.L. (2011). Private climate change reporting: an emerging discourse of risk and opportunity? Accounting, Auditing \& Accountability Journal, 24(8), 1119-1148.

Spence, M. (2002). Signaling in retrospect and the informational structure of markets. American Economic Review, 3, 434-459. 
Stanley, J. D., \& DeZoort, T. F. (2007). Audit firm tenure and financial restatements: An analysis of industry specialization and fee effects. Journal of Accounting and Public Policy, 26(2), 131-159.

Susela, S. D. (1999). "Interests" and accounting standard setting in Malaysia. Accounting, Auditing \& Accountability Journal, 12(3), 358-387.

Tang, Q., Chen, H., \& Lin, Z. (2016). How to measure country-level financial reporting quality? Journal of Financial Reporting and Accounting, 14(2), 230-265.

Wahab, E. A. A., Gist, W. E., \& Majid, W. Z. N. A. (2014). Characteristics of non-audit services and financial restatements in Malaysia. Journal of Contemporary Accounting and Economics, 10(3), 225-247.

Wallace, R. S. O., \& Naser, K. (1995). Firm-specific determinants of the comprehensiveness of mandatory disclosure in the corporate annual reports of firms listed on the Stock Exchange of Hong Kong. Journal of Accounting and Public Policy 14(4), 311-368.

Wallace, R. S. O., Naser, K., \& Mora, A. (1994). The relationship between the comprehensiveness of corporate annual reports and firm characteristics in Spain. Accounting and Business Research, 25(97), 41-53.

Watson, A., Shrives, P., \& Marston, C. (2002). Voluntary disclosure of accounting ratios in the UK. British Accounting Review, 34(4), 289-313.

Weisbach, M. S., \& Hermalin, B. E. (2000). Boards of Directors as an Endogenously Determined Institution: A Survey of the Economic Literature. SSRN Electronic Journal.

Xie, B., Davidson, W. N., \& DaDalt, P. J. (2003). Earnings management and corporate governance: the role of the board and the audit committee. Journal of Corporate Finance, 9(3), 295316.

Yunos, R. M. (2011). The Effect of Ownership Concentration, Board of Directors, Audit Committee and Ethnicity on Conservative Accounting: Malaysian Evidence. PhD Thesis, Edith Cowan University.

Zadeh, F. O. (2015). Corporate governance, risk disclosure and cost of equity capital in the malaysian public listed firm. Phd Thesis, Universiti Teknologi Malaysia

Zadeh, F. O., Zaleha, S., Rasid, A., \& Basiruddin, R. (2016). Risk Disclosure Practices among Malaysian Listed Firms. International Journal of Economics and Financial Issues, 6(3), 4138.

Zaimee, A. (2007). Mini Enrons shaking up Malaysia's corporate governance? Accountant Today, 20(7), 21-23.

Zaluki, N. A. A., \& Hussin, W. N. (2009). Corporate Boards, Audit Committees and Quality of Financial Disclosure in IPOs. SSRN eLibrary. 